\title{
Stabilization, physiochemical and sensory evaluation of mango jam with jaggery stored at ambient temperature $\left(25-30^{\circ} \mathrm{C}\right)$
}

\author{
Muhammad Yaseen ${ }^{1}$, Sumayya Rani ${ }^{1 *}$, Uzma Shahni ${ }^{2}$, Ziaur Rahman ${ }^{1}$, \\ Nabila Khan ${ }^{1}$, Beena Saeed ${ }^{3}$, Jawad Ali Shah ${ }^{4}$ Jamal Abdul Nasir ${ }^{5}$ and \\ Hammad Wahab ${ }^{5}$ \\ 1. Department of Agriculture (Food Science and Technology), University Of Swabi, Anbar Swabi-Pakistan \\ 2. Department of Health and Physical Education, Abdul Wali Khan University Mardan, KPK-Pakistan \\ 3. Department of Agriculture (Agronomy), University Of Swabi, Anbar Swabi-Pakistan \\ 4. Department of Agriculture (Entomology), University Of Swabi, Anbar Swabi-Pakistan \\ 5. Department of Food Science \& Technology, University Of Agriculture, Peshawar-Pakistan \\ *Corresponding author's email: Sumayya@uoswabi.edu.pk \\ Citation \\ Muhammad Yaseen, Sumayya Rani, Uzma Shahni, Ziaur Rahman1, Nabila Khan, Beena Saeed, Jawad Ali Shah, \\ Jamal Abdul Nasir and Hammad Wahab. Stabilization, physiochemical and sensory evaluation of mango jam with \\ jaggery stored at ambient temperature $\left(25-30^{\circ} \mathrm{C}\right)$. Pure and Applied Biology. Vol. 7, Issue 2, pp427-434. \\ http://dx.doi.org/10.19045/bspab.2018.70053
}

Received: 07/12/2017 Revised: 22/03/2018

Accepted: 28/03/2018

Online First: 31/03/2018

\section{Abstract}

The aim of this work was to study physicochemical and sensory characteristics of mango jam prepared with sugar and jaggery individually and in combination. Five treatments were prepared $\left(\mathrm{Mj}_{1}, \mathrm{Mj}_{2}, \mathrm{Mj}_{3}, \mathrm{Mj}_{4}\right.$ and $\left.\mathrm{Mj}_{5}\right)$ and were stored at ambient temperature $\left(25-30^{\circ} \mathrm{C}\right)$. These were analyzed both physicochemically and organoleptically for total time period of 30 days at 15 days interval. During storage the average value of titratable acidity and total soluble solids were increased. Ascorbic acid content, $\mathrm{pH}$ and average score of judges for color, taste, texture and overall acceptability of all samples were decreased $(\mathrm{p}<0.05)$. On the basis of different parameters and analysis, $\mathrm{Mj}_{1}$ (mango pulp50\%+sugar 50\%+ $0.99 \%$ Citric Acid $+0.06 \%$ potassium meta bi sulphite) was found very acceptable both physicochemically and organoleptically during storage. Addition of jaggery to fruit products gives molassic flavor and helps in controlling different diseases in population such as anaemia, asthenia, cough and chest congestion by providing long chain sugars, iron and salts. Future study is recommended to determine microbial count, approximate analysis and mineral content.

Keywords: Jaggery; Jam; Mango; Physicochemical; Sensory characteristics

\section{Introduction}

Jam is a semi-solid food product made by mixing of fruit pulp, sugar along with thickening agent and acids with continuous heating practice. Sometimes other ingredients such as (preservatives, colors, and tasty ingredients) are also added for the best stability and increased edibility $[1,2]$. According to Codex Alementarious commission, the total soluble solids of jam should not be less than $68^{\circ}$ brix. The food products development and formation is the main objective of food industry. Consumer demands for new, best quality and hazard free 
products. It is important to know all the factors and their effects on quality of food products. Consumers are very health conscious towards fruit and vegetable products enriched with nutrients, natural flavor and taste [3].

Mango (Mangifera indica L.) is generally called "king" of fruits because of very attractive color, taste, flavor and very high nutritional value [4]. It is very important commercial and tropical export fruit and about 25.1 million tonnes is produced in almost 90 countries of the world. Pakistan is the $5^{\text {th }}$ largest mango producing country in the world producing about 938 thousand tones (7.6\% share in world market). Mango Anchardian family is one of the most popular tropical fruit [5]. Gallic acid, chlorogenic acid, vanillic acid, gentisyl-protocatechuic acid and mangiferin are phenolic compounds found in mango fruit pulp. These are natural antioxidants used in food, pharmaceutical and cosmetics industries [6].

Jaggery also known as "gur" is very popular un-centrifuged sugar. It is produced from cane juice, beet juice and palm sap. It is uncentrifuged and unrefined sweet product obtained from vacuum boiling of cane syrup. It is consumed worldwide under different names such as gur in Pakistan, rappadura in Brazil, and hakura in Sri Lanka [7]. It is mainly produced and consumed in India, Burma, Indonesia and Pakistan. It has dark colour because of impurities and molasses [8]. Jaggery has about 50\% non-reducing sugars, $20 \%$ reducing sugars and about $20 \%$ moisture content. It provides essential vitamins such as Vit $A, D, E$ and $B$ complexes, Proteins and Minerals $(\mathrm{Ca}, \mathrm{Cu}$, $\mathrm{Mn}, \mathrm{Cl}, \mathrm{P}, \mathrm{K}, \mathrm{Na}$ and $\mathrm{Mg}$ ) [9]. It has complex carbohydrates which are digested slowly and are less harmful for the body. It is not cleared whether jaggery is suitable for diabetic patients or not. It collects considerable amount of ferrous salt (Iron) during its preparation in iron vessels. This iron is good for health especially for those who are anaemic. It is a good source of minerals and salts which are beneficial for body and act as cleansing agents and prevents asthma, cough, cold and congestion in chest [10].

The main objective of this study was to standardize the mango jam with jaggery and to check its physiochemical, organoleptic properties and storage stability at ambient temperature.

\section{Materials and methods \\ Collection of raw materials}

Best quality fresh, mature and juicy mangoes were selected and bought from local fruit market of Peshawar. Jaggery and sugar were purchased and brought to Food processing laboratory of Nuclear Institute for Food and Agriculture Peshawar KPK, Pakistan where research work was carried out.

\section{Extraction of Pulp}

Mangoes were washed, peeled and pulp was extracted with the help of pulper.

\section{Preparation of mango jam}

Pulp was taken into kettles. Jaggery and sugar were added to pulp separately and in combination and cooked until total soluble solid was reached to $63-68{ }^{0}$ Brix. Five glass bottles were taken and labelled as $\mathrm{Mj}_{1}$, $\mathrm{Mj}_{2}, \mathrm{Mj}_{3}, \mathrm{Mj}_{4}$, and $\mathrm{Mj}_{5}$ and preserved with the same quantity of potassium metabisulphite $(0.06 \%)$, Citric acid $(0.90 \%)$ and pectin $(0.5 \%)$. All the samples were stored at ambient temperature $\left(25-30{ }^{\circ} \mathrm{C}\right)$ and analyzed physicochemically (Titratable acidity, Ascorbic acid, pH, TSS) and organoleptically (Color, Taste, Texture and over all acceptably) for 30 days at 15 days interval (Table 1). 
Table 1.Proposed plan of study

\begin{tabular}{|c|c|c|c|}
\hline Treatments & Pulp (\%) & Sugar (\%) & Jaggery (\%) \\
\hline $\mathbf{M j}_{\mathbf{1}}$ & 50 & 50 & $\overline{50}$ \\
\hline $\mathbf{M j} \mathbf{2}$ & 50 & $\overline{25}$ & 25 \\
\hline $\mathbf{M j} \mathbf{3}$ & 50 & 20 & 30 \\
\hline $\mathbf{M j} \mathbf{4}$ & 50 & 50 & 20 \\
\hline $\mathbf{M j}_{\mathbf{5}}$ & 50 & & \\
\hline
\end{tabular}

\section{Physiochemical analysis}

Total soluble solids ( ${ }^{\circ}$ brix) were determined using method no 920.183 by ATAGO Japan hand refractometer (Range $0-90{ }^{0} \mathrm{Brix}$ ), $\mathrm{pH}$ was determined by digital $\mathrm{pH}$ meter using method no 920.183, titratable acidity was determined using method no 920.183 and ascorbic acid determination was done using method no 967.2 as described by [11].

\section{Organoleptic evaluation}

All the samples were analyzed organoleptically (color, flavor, taste, texture and overall acceptability) using nine-points hedonic scale by 10 members as judges who used the standard method as described by [12]. They analyzed all products at fifteen days interval for total time period of 30days.

Statistical analysis

All the results were statistically analyzed by using CRD (completely randomized design) two factorial design conducting two way ANOVA at significance level $(\mathrm{p}<0.05)$ as shown in steel and torrie (1997), All mean values were separated by LSD (least significance difference) test applying All pair wise comparison with the help of statistical software "Statistix 8.1" (Analytical software, Tallahassee, FL USA).

\section{Results and discussion}

Physicochemical analysis

\section{Acidity (\%)}

Mean value of $\%$ acidity in all samples was increased from 1.76 to 2.50. Highest mean value was observed in $\mathrm{Mj}_{3}$ (2.35) followed by $\mathrm{Mj}_{2}$ (2.28) and lowest in $\mathrm{Mj}_{1}$ (1.90) followed by $\mathrm{Mj}_{5}$ (2.00). Highest percent increase was found in $\mathrm{Mj}_{4}$ (38.02) followed by $\mathrm{Mj}_{2}$ (29.85) and lowest in $\mathrm{Mj}_{1}$ (19.04) followed by $\mathrm{Mj}_{3}$ (28.09) (Table 2). The work of [13] also showed the same increasing trend of acidity in their samples of kinnow juice. The same trend of increase in acidity of apple juice samples was also reported by [14].

Table 2. Effect on the Acidity of different mango jaggery jam samples

\begin{tabular}{|c|c|c|c|c|c|}
\hline Treatments & \multicolumn{3}{|c|}{ Storage Interval } & \%increase & Mean \\
\hline & Initial & $\mathbf{1 5}$ & $\mathbf{3 0}$ & & \\
\hline $\mathbf{M j} \mathbf{j}_{1}$ & 1.70 & 1.90 & 2.10 & 19.04 & $1.90 \mathrm{~d}$ \\
\hline $\mathbf{M j}_{2}$ & 1.88 & 2.28 & 2.68 & 29.85 & $2.28 \mathrm{ab}$ \\
\hline $\mathbf{M j} \mathbf{j}_{3}$ & 1.95 & 2.35 & 2.75 & 28.09 & $2.35 \mathrm{a}$ \\
\hline $\mathbf{M j} \mathbf{j}_{4}$ & 1.63 & 2.13 & 2.63 & 38.02 & $2.13 \mathrm{bc}$ \\
\hline $\mathbf{M j}_{5}$ & 1.65 & 2.00 & 2.35 & 29.78 & $2.00 \mathrm{~cd}$ \\
\hline Mean & $1.76 \mathrm{c}$ & $2.13 \mathrm{~b}$ & $2.50 \mathrm{a}$ & & \\
\hline
\end{tabular}




\section{Ascorbic acid (mg/100g)}

Mean values of ascorbic acid in all samples was decreased from 26.81 to 26.25 at $(\mathrm{p}<0.05)$. Highest mean values was observed in $\mathrm{Mj}_{1}$ (28.44) followed by $\mathrm{Mj}_{2}$ (27.22) while lowest was observed in $\mathrm{Mj}_{4}$ (24.74) followed by $\mathrm{Mj}_{3}$ (25.92). Highest percent decrease was observed in $\mathrm{Mj}_{4}$ (2.39\%) followed by $\mathrm{Mj}_{3}$ (2.28) while lowest was observed in $\mathrm{Mj}_{1}$
(1.39\%) followed by $\mathrm{Mj}_{2}$ (2.18) (Table 3). The same declining trend in ascorbic acid content was observed by [13] in kinnow juice during storage. Decrease of ascorbic acid in apple fruit beverage was reported by [14]. The same lowering trend in ascorbic acid was observed in the work of [15] on aqueous orange juice samples.

Table 3. Effect on ascorbic acid content of different mango jaggery jam samples

\begin{tabular}{|c|c|c|c|c|c|}
\hline Treatments & \multicolumn{3}{|c|}{ Storage Interval } & \%Decrease & Mean \\
\hline & Initial & $\mathbf{1 5}$ & $\mathbf{3 0}$ & & \\
\hline $\mathbf{M j}_{1}$ & 28.64 & 28.44 & 28.24 & 1.39 & $28.44 \mathrm{a}$ \\
\hline $\mathbf{M} \mathbf{j}_{\mathbf{2}}$ & 27.52 & 27.22 & 26.92 & 2.18 & $27.22 \mathrm{~b}$ \\
\hline $\mathbf{M} \mathbf{j}_{3}$ & 26.22 & 25.92 & 25.62 & 2.28 & $25.92 \mathrm{~d}$ \\
\hline $\mathbf{M} \mathbf{j}_{4}$ & 25.04 & 24.74 & 24.44 & 2.39 & $24.74 \mathrm{e}$ \\
\hline $\mathbf{M j} \mathbf{j}_{5}$ & 26.66 & 26.36 & 26.06 & 2.25 & $26.36 \mathrm{c}$ \\
\hline Mean & $26.81 \mathrm{a}$ & $26.53 \mathrm{~b}$ & $26.25 \mathrm{c}$ & & \\
\hline
\end{tabular}

\section{pH}

Mean value of $\mathrm{pH}$ significantly $(\mathrm{p}<0.05)$ decreased from 3.83 to 3.71 . Highest mean value was observed in $\mathrm{Mj}_{2}$ (4.16) followed by $\mathrm{Mj}_{4}$ (3.85) while lowest in $\mathrm{Mj}_{1}$ (3.48) followed by $\mathrm{Mj}_{3}$ (3.66). Highest percent decrease was observed in $\mathrm{Mj}_{2}(3.30 \%)$ followed by $\mathrm{Mj}_{3}$ (3.22) and lowest was observed in $\mathrm{Mj}_{1}(2.27 \%)$ followed by $\mathrm{Mj}_{4}$ (3.06) (Table 4). The same decreasing trend in $\mathrm{pH}$ of kinnow juice was reported by [16]. The decrease in $\mathrm{pH}$ is due to formation of acidic compounds by degradation of reducing sugars as discussed by [17]. The reduction in $\mathrm{pH}$ could be attributed to simultaneous increase in acidity and total soluble solids of nectar at storage temperature as reported by $[18]$ in the squash of pomegranate.

Table 4. Effect on $\mathrm{pH}$ of different mango jaggery jam samples

\begin{tabular}{|c|c|c|c|c|c|}
\hline Treatments & \multicolumn{3}{|c|}{ Storage interval } & \% Decrease & Mean \\
\hline & Initial & $\mathbf{1 5}$ & $\mathbf{3 0}$ & & \\
\hline $\mathbf{M j} \mathbf{j}_{1}$ & 3.52 & 3.48 & 3.44 & 2.27 & $3.48 \mathrm{e}$ \\
\hline $\mathbf{M j}$ & 4.23 & 4.16 & 4.09 & 3.30 & $4.16 \mathrm{a}$ \\
\hline $\mathbf{M j}$ & 3.72 & 3.66 & 3.60 & 3.22 & $3.66 \mathrm{~d}$ \\
\hline $\mathbf{M j}$ & 3.91 & 3.85 & 3.79 & 3.06 & $3.85 \mathrm{~b}$ \\
\hline $\mathbf{M j} \mathbf{j}_{5}$ & 3.78 & 3.72 & 3.66 & 3.17 & $3.72 \mathrm{c}$ \\
\hline $\mathbf{M e a n}$ & $3.83 \mathrm{a}$ & $3.77 \mathrm{~b}$ & $3.71 \mathrm{c}$ & & \\
\hline
\end{tabular}

\section{Total soluble solids ( ${ }^{\circ}$ brix $)$}

Mean value of total soluble solids was significantly $(\mathrm{p}<0.05)$ increased from 64.4 to $67.8^{\circ}$ brix. Highest mean value was observed in $\mathrm{Mj}_{5}$ (67.66) followed by $\mathrm{Mj}_{4}$ (66.00) while lowest in $\mathrm{Mj}_{2}$ (64.66) followed by $\mathrm{Mj}_{1}$ (65.00). Highest percent increase was found in $\mathrm{Mj}_{2}(5.97 \%)$ followed by $\mathrm{Mj}_{3}$ (5.88) while 
lowest in $\mathrm{Mj}_{1}$ (3.03) followed by $\mathrm{Mj}_{5}$ (4.34) (Table 5). The same increasing trend in total soluble solids of pineapple juice samples were reported by [19] in his orange and pineapple juice samples. The same increase in total soluble solids in apple pulp samples were reported by [20].

Table 5. Effect on total Soluble Solids of different mango jaggery jam samples

\begin{tabular}{|c|c|c|c|c|c|}
\hline Treatments & \multicolumn{3}{|c|}{ Storage Interval } & \% Increase & Mean \\
\hline & Initial & $\mathbf{1 5}$ & $\mathbf{3 0}$ & & \\
\hline $\mathbf{M j}_{1}$ & 64 & 65 & 66 & 3.03 & $65.00 \mathrm{~cd}$ \\
\hline $\mathbf{M j}_{2}$ & 63 & 64 & 67 & 5.97 & $64.66 \mathrm{~d}$ \\
\hline $\mathbf{M j}_{3}$ & 64 & 66 & 68 & 5.88 & $66.00 \mathrm{bc}$ \\
\hline $\mathbf{M j}_{4}$ & 65 & 66 & 69 & 5.79 & $66.66 \mathrm{ab}$ \\
\hline $\mathbf{M j} 5$ & 66 & 68 & 69 & 4.34 & $67.66 \mathrm{a}$ \\
\hline Mean & $64.4 \mathrm{c}$ & $65.8 \mathrm{~b}$ & $67.8 \mathrm{a}$ & & \\
\hline
\end{tabular}

\section{Organoleptic evaluation}

Color

Mean score of judges for color significantly decreased from 6.82 to 6.00 at $(\mathrm{p}<0.05)$. Highest average score for color was observed in $\mathrm{Mj}_{1}$ (8.66) followed by $\mathrm{Mj}_{2}$ (7.26) and lowest in $\mathrm{Mj}_{4}$ (4.50) followed by $\mathrm{Mj}_{3}$ (5.50). Highest percent decrease was observed in $\mathrm{Mj}_{4}$ (20.00) followed by $\mathrm{Mj}_{2}$
(7.26) while lowest in $\mathrm{Mj}_{1}$ (5.55) next was $\mathrm{Mj}_{2}$ (6.66) in (Table 6). The [21] also reported the same decreasing trend in judges score for color of samples. These findings are in similarity with the findings of [22] who worked on different fruit juice blends and studied gradual decrease in score for color.

Table 6. Effect on color points of different mango jaggery jam samples

\begin{tabular}{|c|c|c|c|c|c|}
\hline Treatments & \multicolumn{3}{|c|}{ Storage Interval } & \% Decrease & Mean \\
\hline & Initial & $\mathbf{1 5}$ & $\mathbf{3 0}$ & & \\
\hline $\mathbf{M j}_{1}$ & 9.0 & 8.5 & 8.5 & 5.55 & $8.66 \mathrm{a}$ \\
\hline $\mathbf{M j}_{2}$ & 7.5 & 7.3 & 7.0 & 6.66 & $7.26 \mathrm{~b}$ \\
\hline $\mathbf{M j}_{3}$ & 6.0 & 5.5 & 5.0 & 16.66 & $5.50 \mathrm{~d}$ \\
\hline $\mathbf{M j}_{4}$ & 5.0 & 4.5 & 4.0 & 20.00 & $4.50 \mathrm{e}$ \\
\hline $\mathbf{M j} \mathbf{j}_{5}$ & 6.6 & 6.0 & 5.5 & 16.66 & $6.03 \mathrm{c}$ \\
\hline Mean & $6.82 \mathrm{a}$ & $6.36 \mathrm{~b}$ & $6.00 \mathrm{c}$ & & \\
\hline
\end{tabular}

\section{Taste}

Mean score of judges for taste was significantly decreased from 6.96 to 6.06 $(\mathrm{p}<0.05)$. Highest mean score for taste was observed in $\mathrm{Mj}_{1}$ (8.66) followed by $\mathrm{Mj}_{2}$ (7.50) and lowest in $\mathrm{Mj}_{4}$ (4.50) followed by $\mathrm{Mj}_{3}$ (5.73). Highest \% decrease in judges score for taste was observed in $\mathrm{Mj}_{4}$ (20.00) followed by $\mathrm{Mj}_{3}(15.87)$ and lowest in $\mathrm{Mj}_{1}$ (5.55) followed by $\mathrm{Mj}_{2}$ (12.50) (Table 7).
These results are in agreement with the work of [16] who observed that the flavor of spiced beverages has higher rating at initial stage but decrease significantly with time.

\section{Texture}

Mean score of judges for texture was significantly decreased from 6.60 to 5.70 $(p<0.05)$. Highest mean score of judges for texture was observed in $\mathrm{Mj}_{1}$ (8.66) followed by $\mathrm{Mj}_{2}$ (7.00) and lowest in $\mathrm{Mj}_{4}$ (4.50) 
followed by $\mathrm{Mj}_{3}$ (5.00). Highest \% decrease in taste score was observed in $\mathrm{Mj}_{4}$ (20.00) followed by $\mathrm{Mj}_{3}$ (18.18) and lowest in $\mathrm{Mj}_{1}$ (5.5) followed by $\mathrm{Mj}_{2}$ (13.33) (Table 8). These results are in agreement with the results of [23] on orange drink.

\section{Overall acceptability}

Mean score of judges for overall acceptability was significantly decreased from 7.06 to $6.24(\mathrm{p}<0.05)$.Highest mean score of judges was observed in $\mathrm{Mj}_{1}$ (8.60) followed by $\mathrm{Mj}_{2}$ (7.53) while lowest was observed in $\mathrm{Mj}_{5}$ (5.06) followed by $\mathrm{Mj}_{4}$ (5.50). Highest \%decrease in score for overall acceptability was observed in $\mathrm{Mj}_{4}$ (16.66) followed by $\mathrm{Mj}_{5}$ (14.54) and lowest in $\mathrm{Mj}_{1}$ (4.54) followed by $\mathrm{Mj}_{2}$ (11.25) in (Table 9). The results are in agreement with the results of $[24,25]$ who showed that organoleptic rating of freshly prepared product were high and reduced significantly with storage.

Table 7. Effect on taste of different mango jaggery jam samples

\begin{tabular}{|c|c|c|c|c|c|}
\hline Treatments & \multicolumn{2}{|c|}{ Storage Interval } & \% Decrease & Mean \\
\hline & Initial & $\mathbf{1 5}$ & $\mathbf{3 0}$ & & \\
\hline $\mathbf{M j}_{1}$ & 9.0 & 8.5 & 8.5 & 5.55 & $8.66 \mathrm{a}$ \\
\hline $\mathbf{M j}_{2}$ & 8.0 & 7.5 & 7.0 & 12.50 & $7.50 \mathrm{~b}$ \\
\hline $\mathbf{M j}_{3}$ & 6.3 & 5.6 & 5.3 & 15.87 & $5.73 \mathrm{~d}$ \\
\hline $\mathbf{M j}_{4}$ & 5.0 & 4.5 & 4.0 & 20.00 & $4.50 \mathrm{e}$ \\
\hline $\mathbf{M j}$ & 6.5 & 6.0 & 5.5 & 15.38 & $6.00 \mathrm{c}$ \\
\hline Mean & $6.69 \mathrm{a}$ & $6.42 \mathrm{~b}$ & $6.06 \mathrm{c}$ & & \\
\hline
\end{tabular}

Table 8. Effect on texture of different mango jam samples

\begin{tabular}{|c|c|c|c|c|c|}
\hline \multirow{2}{*}{ Treatments } & \multicolumn{2}{|c|}{ Storage Interval } & \multirow{2}{*}{ \% Decrease } & \multirow{2}{*}{ Mean } \\
\cline { 2 - 4 } & Initial & $\mathbf{1 5}$ & $\mathbf{3 0}$ & & $8.66 \mathrm{a}$ \\
\hline $\mathbf{M j}_{1}$ & 9.0 & 8.5 & 8.5 & 5.55 & $7.00 \mathrm{~b}$ \\
\hline $\mathbf{M j}_{2}$ & 7.5 & 7.0 & 6.5 & 13.33 & $5.00 \mathrm{~d}$ \\
\hline $\mathbf{M j}_{3}$ & 5.5 & 5.0 & 4.5 & 18.18 & $4.50 \mathrm{e}$ \\
\hline $\mathbf{M j}_{4}$ & 5.0 & 4.5 & 4.0 & 20.00 & $5.50 \mathrm{c}$ \\
\hline $\mathbf{M j} \mathbf{j}_{5}$ & 6.0 & 5.5 & 5.0 & 16.66 & \\
\hline Mean & $6.60 \mathrm{a}$ & $6.10 \mathrm{~b}$ & $5.70 \mathrm{c}$ & & \\
\hline
\end{tabular}

Table 9.Effect on overall acceptability of mango jam samples

\begin{tabular}{|c|c|c|c|c|c|}
\hline Treatments & \multicolumn{2}{|c|}{ Storage Interval } & \%Decrease & Mean \\
\hline & Initial & $\mathbf{1 5}$ & $\mathbf{3 0}$ & & \\
\hline $\mathbf{M j}_{1}$ & 8.8 & 8.6 & 8.4 & 4.54 & $8.60 \mathrm{a}$ \\
\hline $\mathbf{M j}$ & 8.0 & 7.5 & 7.1 & 11.25 & $7.53 \mathrm{~b}$ \\
\hline $\mathbf{M j}_{3}$ & 7.0 & 6.5 & 6.0 & 14.28 & $6.50 \mathrm{c}$ \\
\hline $\mathbf{M j}_{4}$ & 6.0 & 5.5 & 5.0 & 16.66 & $5.50 \mathrm{~d}$ \\
\hline $\mathbf{M j} \mathbf{j}_{5}$ & 5.5 & 5.0 & 4.7 & 14.54 & $5.06 \mathrm{e}$ \\
\hline Mean & $7.06 \mathrm{a}$ & $6.62 \mathrm{~b}$ & $6.24 \mathrm{c}$ & & \\
\hline
\end{tabular}

\section{Conclusion and recommendations}

From this study it was concluded that Potassium metabisulphite, citric acid, pectin and sugar has strong effect on overall quality of $\mathrm{Mj}_{1}$ (50\% mango pulp+ 50\% Sugar + Citric acid $(0.90 \%)+$ potassium metabisulphite 
$(0.06 \%$ +pectin $(0.5)$ and remained acceptable during 30 days of storage. In future further study is recommended on microbial count, approximate analysis and mineral content.

\section{Authors' contributions}

Conceived and designed the experiments: $\mathrm{M}$

Yaseen \& $\mathrm{S}$ Rani, Performed the experiments: $M$ Yaseen, $H$ Wahab \& U Shahni, Analyzed the data: N Khan, B Saeed \& Z Rahman, Contributed materials/ analysis/ tools: JA Shah \&, JA Nasi, Wrote the paper: S Rani, U Shahni \& B Saeed.

\section{Acknowledgement}

The present study was supported by Nuclear Institute for Food and Agriculture Peshawar KPK, Pakistan.

\section{References}

1. Lal G, Siddappaa GS \& Tandon GL (1998). Preservation of Fruit and Vegetables. ICAR Publication, New Delhi India.

2. Baker RA, Berry N, Hui, YH \& Barrett DM (2005). Food preserves and jams. In Processing fruit science and technology $2^{\text {nd }}$ (ed) CRC press, Boca raton, Fl (USA) pp 113-125.

3. Renard D, Velde VDF \& Vischers RW (2006). The gap between food gel structure, texture and perception. Food Hydrocolloids (20): 423-431.

4. Sauco VG (2002). Magazine of Chronica Horticulturae. Int Soc Hort Sci 42: 14-17.

5. Agric Stat of Pakistan (2011-12). Fruits vegetables and condiments statistics of Pakistan. Govt of Pakistan. Ministry of food and livestock (Economic Wing) Islamabad Pakistan 1-89.

6. Tunchaiyaphum S, Eshtiaghi MN \& Yoswathana N (2013). Extraction of bioactive compounds from mango peels using green technology. Inter $J$ of Chemical Engineering and Applications 4(4): 194.

7. Vinutha C, Sudarshan C, Pradeep S \& Nayaka H (2014). Health effects of non- centrifugal sugar (NCS). A Review 5(1): 99-101.

8. Pattnayak PK \& Misra MK (2004). Energetic and economics of traditional gur preparation. A case study in Ganjam District of Orissa (India). Biomass and Bioenergy 26: 79-88.

9. Rao PVK, Das M \& Das SK (2007). Jaggery a traditional Indian sweetener. Ind J of Trad Knowledge 6(1): 95-102.

10. Nath A, Dutta D, Pawan K \& Singh JP (2015). Review on recent advances in value addition of jaggery based products. J Food Process Technol 6:4.

11. AOAC (2012). Official Methods of Analysis, volume II.Official method of analysis of association of official Analytical Chemists Gaithersburg (USA) $19^{\text {th }}$ ed.

12. Larmand E (1977). Lab. Method of sensory evaluation of food. Pub Canada Deptt Agric Ottawa.

13. Sandhu KS \& Singh S (2001). Studies on the factors affecting the physicochemical and organoleptic of kinnow juice. J Food Sci \& Tech 38(3): 266-269.

14. Mehmood Z, Zeb A, Ayub M, Bibi N, Badshah A \& Ullah I (2008). Effect of pasteurization and chemical preservatives on the quality and shelf life stability of apple juice. Amer J Food Tech 3(2):147-153.

15. Moshonas MG \& Shaw PE (1990). Flavor evaluation of concentrated aqueous juice orange essences. J of Agri Food Chem 38(12): 2182-2184.

16. Dhaka A, Sharma M \& Singh SK (2016). Use of additives to reduce browning, microbial load and quality loss of kinnow juice under ambient storage. Ind $J$ of Sci and Technology 9(14).

17. Zia MA (1987). Production and characterization of fruit juice blend of mango, pomegranate and guava. MSc Thesis Deptt of Food tech Univ Agric Faisalabad. Ind J of Hort 50(4): 327-332. 
18. Prasad RN \& Mali PC (2000). Changes in physico-chemical characteristics of pomegranate squash during storage. Ind J of Horticulture 57(1): 18-20.

19. Islam MA, Ahmad I, Ahmed S \& Sarker A (2015). Biochemical composition and shelf life study of mixed fruit juice from orange \& pineapple. $J$ of Environmental Sci and Natural Resources 7(1): 227232.

20. Kinh Shearer AEH, Dunne CP \& Hoover DG (2001). Preparation and preservation of apple pulp with chemical preservatives and mild heat. J of Food Prot 28 (6): 111114.

21. Brenndor, Kennedy CO, Oswin DST, Mrema GC \& Werek C (1985). Bobby solar driers their role in postharvest processing. Common Wealth Sci Council: 78-83.

22. Jain SK \& Khurdiya DS (2004). Vitamin $\mathrm{C}$ enrichment of fruit juice based ready- to-serve beverages through blending of Indian gooseberry (Emblica officianlis Gaertn) juice. Plant Foods for human nutrition 59: 63-66.

23. Jain S, Sankhla APK, Dashora A \& Sankhla AK (2003). Physiochemical and sensory properties of orange drink. $J$ Food Sci Tech Ind 40(6): 656-659.

24. Sharma SK, Chaudary SP, Rao VK, Yadav VK \& Bisht TS (2013). Standardization of technology for preparation and storage of wild apricot fruit bar. J Food Sci Tech 50: 784-790.

25. Khan SH, Khan A, Litaf U, Shah AS, Khan MA, Ali MS, Shah FN, Maqbool Z, Adnan M \& Rani S (2015). Effect of different concentrations of guava pulp, apple pulp and sugar solution on the shelf stability of blend leather storage at ambient temperature. J Food Process Technol 6: 7. 